\title{
Analysis of the Status Quo and Development Trend of Financial Reform in Laos
}

\author{
Tang Liujie* \\ Economics School \\ Yunnan University of Finance and Economics \\ Kunming, China \\ yyw1101@163.com
}

\author{
Zhu Tong \\ Economics School \\ Yunnan University of Finance and Economics \\ Kunming, China \\ 460799325@qq.com
}

\begin{abstract}
This paper selected the economic indicators through 1997-2016 of Laos, carried out ADF test, co-integration test and Granger test, deleted the variables that did not have causality, and then selected the economic variables related to economic growth in Laos and analyzed the trend of development of Laos financial reform.. On this basis, it concludes the savings rate, credit scale and international cooperation which will improve Laos' financial reform and economic growth. As the implementation of the "One Belt, One Road" opening-up policy of China in recent years, the cooperation between China and Laos is becoming increasingly close. This paper suggests that future cooperation may focus on the financial area. It will help to gain mutual benefits.
\end{abstract}

Keywords-China; Laos; Financial reform; Economic

\section{INTRODUCTION}

As peace and development become the main themes of the present era, the world has unified as a whole. No country can develop without cooperating with other countries. To speed up the pace of the economic development, China needs to cooperate with other countries, especially those neighbors. In recent years, with the national "One Belt, One Road" strategy turned from the concept into action, China conducts more and more studies on the financial reform of its neighbors, especially Laos and other Southeast Asian countries. As these countries are both closely related to China in geography, it's convenient for them to cooperate with each other.

Since the reform and opening-up policy put forward in 1986, the economy has increased a lot. Although China started economic reform earlier than Laos, with more and more communication and cooperation between the two countries, their economic ties become stable. Therefore, an analysis of the status quo and development trend of the financial reform in Laos helps to strengthen the cooperation between the two countries. In addition, the current national economic conditions and policies of Laos can accelerate the "One Belt, One Road" strategy carried out in Laos. The two countries are traditionally good neighbors and have common interests in many areas. With the help of the cooperation, Laos has become the bridge linking China and the Association of Southeast Asian Nations (ASEAN).

He Yangyu (2016) ${ }^{[1]}$ considers that, the "One Belt, One Road" has great influence not only on the Asian-Pacific Region but also over the world. It will promote further cooperation between China and Laos. Rashami (2013) ${ }^{[2]}$ studies the relationship between the financial development and economic growth of Laos on the basis of Granger causality test and suggests that, Laos should develop its financial service to promote the economic growth. Guo Yong (2011) ${ }^{[3]}$ suggests expanding investment and trade to deepen the financial development of Laos. Liu Ding (2017) ${ }^{[4]}$ considers that China and Laos have maintained good bilateral relationship and the "One Belt, One Road" strategy will deepen the cooperation between the two countries. In the financial sector, Industrial and Commercial Bank of China, Bank of China, Fudian Bank have cooperated with Laos successively. The Chinese strategy will bring huge financial needs to Laos including investment financing needs in the construction of strategic projects, crossborder use of RMB, the induced insurance needs of the projects. China's financial institutions dedicate to building a financial service network between the two countries and accelerating the financial development of Laos.

Chen Shuqiong (2009) ${ }^{[5]}$ points out that Laos' reform has been effective, but the level of productivity is still low. Laos is still a developing country. Poverty alleviation goal has not been completed. Therefore, Laos should recognize the nature of the reform, focus on the economic development, promote the productivity, and establish the socialist market economy system. Kang Weilai (2007) ${ }^{[6]}$ analysis the institutional problems of Laos' state-owned banks caused by the lag of financial reform. The main problems include that the stateowned commercial banks have no perfect property rights system, efficient organization and operation system. Loan structure and quality defects, capital inadequacy ratio and management system inefficiency, integration of government administration with enterprise highlight the problems.

Most scholars pay more attention to the qualitative analysis of Laos' financial reform, lack of quantitative analysis. The paper tries to explore the quantitative relationship between the changes in the financial indicators and the economic growth in Laos. Then it could explain that in order to promote economic growth more significantly, Laos will undoubtedly make changes to the indicators to promote economic development, especially though cooperation with other countries. It is also possible to forecast the changes in the financial indicators of Laos, explore its development trend and draw the final conclusion. 
All in all, with the economic relations closer, exploring the status quo and development trend of the financial reform in Laos is of great significance to the cooperation between the two countries.

\section{THE CURRENT ECONOMIC DEVELOPMENT OF LAOS}

\section{A. The Current Development of Laos}

As one of the least developed economies in the world, Laos received a lot of foreign aids, which were mainly used for infrastructure projects, such as roads, bridges, docks, hydroelectric plants, water conservancy facilities and so on. These helped a lot for the shortage of capital. Since 1986, Laos has begun to adjust its economic structure, including replacing the highly centralized economic system by the business accounting system and striving to transform the natural and semi-natural economy into market economy. As for the external world, Laos issued the foreign investment laws to improve the domestic and international investment environment. It also expands economic relations with foreign countries to introduce more funds, technologies and management methods. It was right after the reform and opening up that the tertiary industry of Laos began to develop, such as the service industry, the tourism industry and so on. In addition, the government started to allow the foreign-funded enterprises to set up foreign-owned enterprises or join ventures in Laos and repatriate their profits in April 1994 when the National Assembly of Laos passed foreign investment laws.

During 30 years, Laos has made progress in all economic areas. The GDP growth rate is steady (Table 1). The inflation is under control. Market economy was established and the share of the private economy has increased. Many reforms were carried out in rural areas. According to the United Nations Statistics Division, in 2015, the global economic growth rate was $3.1 \%$. The slowdown in global economic growth has led to a weakness in Laos commodity export demand. However, due to the inflow of foreign direct investment, Laos economic development momentum is still strong. The Laos' annual GDP growth rate in 2015 was $6.9 \%$. The money supply (M2) increased by $14.7 \%$. Savings deposits to GDP increased by $53.9 \%$. Credit accounted for $48.1 \%$ of GDP. The ratio of bad loans was $3 \%$. In addition, the overall inflation rate was $1.28 \%$. The exchange rate of Lao Kip to US dollar depreciated by $1.14 \%$.

TABLE I. GRoss Domestic Product Growth IN LAOS (1995-2015, MILLION DOLLARS)

\begin{tabular}{c|c|c|c|c|c|c|c}
\hline Year & 1995 & 1996 & 1997 & 1998 & 1999 & 2000 & 2001 \\
\hline GDP & 1,880 & 1,956 & 1,846 & 1,300 & 1,422 & 1,572 & 1,565 \\
\hline $\begin{array}{l}\text { Growth } \\
\text { Rate (\%) }\end{array}$ & 7.0 & 6.9 & 6.9 & 4.4 & 4.1 & 6.3 & 6.9 \\
\hline Year & 2002 & 2003 & 2004 & 2005 & 2006 & 2007 & 2008 \\
\hline GDP & 1,656 & 2,033 & 2,374 & 2,717 & 3,548 & 4,217 & 5292 \\
\hline $\begin{array}{l}\text { Growth } \\
\text { Rate (\%) }\end{array}$ & 6.9 & 6.2 & 7.0 & 6.8 & 8.6 & 7.8 & 7.80 \\
\hline Year & 2009 & 2010 & 2011 & 2012 & 2013 & 2014 & 2015 \\
\hline GDP & 5,582 & 6,842 & 8,062 & 9,400 & 10,788 & 11,851 & 12,561 \\
\hline $\begin{array}{l}\text { Growth } \\
\text { Rate (\%) }\end{array}$ & 7.5 & 8.1 & 8.0 & 7.9 & 8.0 & 8.0 & 6.9 \\
\hline
\end{tabular}

Source: https:// countryeconomy.com/gdp/laos

\section{B. The Financial Reform of Laos}

In 1986, Laos began to implement the financial reform and achieved some results including various tax systems and the relevant laws, the gap between deposit rate and loan interest rate narrowed and the USD/LAK exchange rate rose. In addition, Laos has also made a lot of efforts to attract foreign investments. Driven by foreign investments, Lao GDP has increased significantly. With further development of economy and trade, Laos' financial system has been improved.

\section{1) Laos' Banking System}

In August 1987, the Central Committee of the Lao People's Revolutionary Party (LPRP) putted forward the plan of economic reform. With the advancement of economic reform over the past three decades, Laos has made remarkable achievements in the development of its banking industry and established a new banking system.

Moreover, it has also improved the internal structures of its banks. From 1997 to now, the total assets of Lao commercial banks have been increasing not only in Lao Kip savings but also in US dollar savings. In addition to the1998 and 2008 financial crisis that the growth rate of Kip assets declined, but in other years, they were stable. At the same time, the dollar savings has increased, especially after the financial reform. With the world economy closer, Laos' dollar savings rate increased steadily. To keep the fiscal deficit at a reasonable level, Laos had strict control on project investments. In 2016, the growth rate of credit was slowed down and fell to $17.92 \%$. Now, problems faced by Laos' commercial banks mainly include as follows:

- Firstly, the high non-performing loan ratio hinders the further development of commercial banks.

- Secondly, due to the poor ability to resist risks, it's easy for them to be impacted by various risky factors.

- Third, the level of legalization and standardization is low. Various laws, regulations and normative systems need to be improved in time.

Therefore, the reform of Laos' commercial banks should be pushed to improve the quality of assets and the governance structure, promote financial innovation and so on.

\section{2) Laos' Securities Market}

Though the securities market founded late in Laos, through the construction in recent years, it has developed and formed a system with its own characteristics. Although Laos' securities market could be the smallest securities market in the world, it's foundation is a milestone in the development of the financial industry of Laos. In the next few years, the development of Laos' securities market will become an important driving force for its economic development.

For now, Laos' securities market is devoting to complete the following aspects: First, it should make the public companies bigger and stronger to enhance the financing capacity of its securities market. Second, it should build a multi-level securities market. Third, it should improve the market supervision and management efficiency. 


\section{3) Laos' Insurance Industry}

"Authorized insurance companies in Laos must be corporate enterprises engaged in the insurance business and with legal personality, including state-owned enterprises, joint ventures, private enterprises and branches of foreign insurance companies" ${ }^{1}$. Besides, according to Laos' laws and regulations in this field, these institutions must obtain business and investment permits from relevant institutions of Laos. In addition, authorized insurance companies must comply with Laos' related laws and regulations in the course of business.

Now, foreign insurers are allowed to invest in Laos. Many Lao insurance companies also build a good reputation, achieve abundant profit and have the ability to provide a series of health products for individual and institutional consumers. With the improvement of various laws and regulations, the insurance industry of Laos will develop further.

\section{MODEL AND REGRESSION ANALYSIS}

\section{A. Selection of Indicators and Sources of Data}

The original data used in this study are mainly from "Laos Statistical Yearbook" (National Bureau of Statistics, from 1997 to 2015), "Bank of Lao P.D.R." (From 1997 to 2015) and "National Risk Analysis Report" (2016).

As growth rate of GDP can reflect the economic growth of a country or a region, the growth rate of Laos' GDP is taken as the dependent variable in this study. And as for the selection of the independent variables, these data are shown in Table 2.

TABLE II. OVERVIEW OF LAO ECONOMIC INDEXES

\begin{tabular}{|c|c|c|c|c|}
\hline variable & Description & Maximum & Minimum & Average \\
\hline $\boldsymbol{Y}$ & Growth Rate of GDP(\%) & 8.60 & 4.1 & 7.05 \\
\hline$X_{1}$ & Inflation rates (\%) & 141.97 & 0.00 & 18.31 \\
\hline$X_{2}$ & Money Supply Growth(\%) & 113.28 & 8.33 & 34.87 \\
\hline$X_{3}$ & Interest Rate(\%) & 22.00 & 5.25 & 12.67 \\
\hline$X_{4}$ & $\begin{array}{c}\text { Total Debt stock ratio to } \\
G D P(\%)\end{array}$ & 101.00 & 38.56 & 59.80 \\
\hline$X_{5}$ & $\begin{array}{l}\text { Commercial Bank } \\
\text { Savings(\%)(Kip) }\end{array}$ & 22.00 & 0.99 & 6.68 \\
\hline$X_{6}$ & $\begin{array}{c}\text { Commercial Bank } \\
\text { Savings(\%)(U.S .dollar) }\end{array}$ & 5.00 & 0.19 & 1.28 \\
\hline$X_{7}$ & Lending rates(\%) & 36.00 & 10.00 & 20.53 \\
\hline - & $\begin{array}{c}\text { Exchange Rate (Kip per } \\
\text { Dollar) }\end{array}$ & 10810.27 & 1259.48 & 8140.27 \\
\hline$X_{8}$ & $\begin{array}{c}\text { Exchange rates (taking } \\
\text { logarithms) }\end{array}$ & - & - & - \\
\hline$X_{9}$ & Growth Rate of Credit(\%) & 142.32 & -5.91 & 42.30 \\
\hline
\end{tabular}

Source: Laos Statistical Yearbook and National Risk Analysis Report

\section{B. Regression Analysis}

To explain the relationship between the financial reforms and economic growth, the study conducts the ADF unit root test, co-integration test and Granger causality test. The model is expressed as below:

$Y=\beta_{0}+\beta_{1} X_{1}+\beta_{2} X_{2}+\beta_{3} X_{3}+\beta_{4} X_{4}+\beta_{5} X_{5}+\beta_{6} X_{6}+\beta_{7} X_{7}+\beta_{8} X_{8}+\beta_{9} X_{9}+\mu(1)$

To ensure the data are stationary, the analysis conducts the ADF unit root test firstly. $Y, X_{3}, X_{4}, X_{5}, X_{6}, X_{7}, X_{8}$, and $X_{9}$ are

\footnotetext{
${ }^{1}$ Insurance Law of Laos in 1990.
}

non-stationary and only $X_{1}$ and $X_{2}$ are stationary at the 5\% level of significance test. Neither the co-integration test nor the regression test could be done directly.

To modify the model, the study takes logarithms for some items and conducts the ADF unit root test again (Table 3). The test results show that all the variables are stationary after the logarithm process. There might be a co-integration relationship between the variables.

TABLE III. TEST RESUlTS TAKING THE LOGARITHMS OF FIRST-ORDER LAG VARIABLES

\begin{tabular}{|c|c|c|}
\hline Variables & Prob. $^{*}$ & Conclusions \\
\hline$D \ln Y$ & 0.0000 & Stationary \\
\hline$D \ln X_{1}$ & 0.0005 & Stationary \\
\hline$D \ln X_{2}$ & 0.0001 & Stationary \\
\hline$D \ln X_{3}$ & 0.0027 & Stationary \\
\hline$D \ln X_{4}$ & 0.0000 & Stationary \\
\hline$D \ln X_{5}$ & 0.0001 & Stationary \\
\hline$D \ln X_{6}$ & 0.0020 & Stationary \\
\hline$D \ln X_{7}$ & 0.0009 & Stationary \\
\hline$D \ln X_{8}$ & 0.0011 & Stationary \\
\hline$D \ln X_{9}$ & 0.0004 & Stationary \\
\hline
\end{tabular}

To analyze whether there is a co-integration relationship between $Y$ and all the independent variables, the study conducts regression analysis before testing the stationary of the data. And the test results show that there is no unit root in the residual series. There is a co-integration relationship between the dependent variable $Y$ and the independent variables. In other words, there is a long-term equilibrium relationship between Laos' GDP growth rate and the financial development.

To tell whether there exists a causal relationship between them, the Granger causal tests need to be done (Table 4).

TABLE IV. GRANGER TEST RESULTS

\begin{tabular}{|c|c|c|c|}
\hline Null Hypothesis & F-Statistic & Prob. & Conclusions \\
\hline$D X 1$ does not Granger Cause $D Y$ & 0.01693 & 0.9832 & Accept \\
$D Y$ does not Granger Cause $D X 1$ & 0.75102 & 0.4928 & Accept \\
\hline$D X 2$ does not Granger Cause $D Y$ & 1.06511 & 0.3751 & Accept \\
$D Y$ does not Granger Cause $D X 2$ & 0.03919 & 0.9617 & Accept \\
\hline$D X 3$ does not Granger Cause $D Y$ & 0.68396 & 0.5232 & Accept \\
$D Y$ does not Granger Cause $D X 3$ & 1.25769 & 0.3192 & Accept \\
\hline$D X 4$ does not Granger Cause $D Y$ & 1.38491 & 0.2876 & Accept \\
$D Y$ does not Granger Cause $D X 4$ & 0.31595 & 0.7350 & Accept \\
\hline$D X 5$ does not Granger Cause $D Y$ & 4.27739 & 0.0396 & Refuse \\
$D Y$ does not Granger Cause $D X 5$ & 0.18287 & 0.8352 & Accept \\
\hline$D X 6$ does not Granger Cause $D Y$ & 3.76943 & 0.0537 & Refuse \\
$D Y$ does not Granger Cause $D X 6$ & 0.64366 & 0.5426 & Accept \\
\hline$D X 7$ does not Granger Cause $D Y$ & 0.49339 & 0.6224 & Accept \\
$D Y$ does not Granger Cause $D X 7$ & 0.04937 & 0.9520 & Accept \\
\hline$D X 8$ does not Granger Cause $D Y$ & 1.90315 & 0.1915 & Accept \\
$D Y$ does not Granger Cause $D X 8$ & 4.06802 & 0.0448 & Refuse \\
\hline$D X 9$ does not Granger Cause $D Y$ & 3.80673 & 0.0525 & Refuse \\
$D Y$ does not Granger Cause $D X 9$ & 0.03395 & 0.9667 & Accept \\
\hline
\end{tabular}

The variable DlnY is written as DY, so are the other variables. 
The results show these conclusions at the $10 \%$ level of significance test:

- The increasing of the commercial banks' savings is the Granger cause for the growth rate of GDP. But the growth rate of GDP is not the Granger cause for the growth of the commercial banks' savings.

- The GDP growth rate is the Granger cause for the growth rate of exchange rates, while the growth rate of exchange rates is not the Granger cause for the growth rate of GDP.

- The growth rate of credit is the Granger cause for the growth rate of GDP, but the growth rate of GDP is not the Granger cause for the growth rate of credit.

There is no Granger causal relationship between other variables and economic growth rates.

Regression relation between Laos' financial development and the economic growth is expressed as follows:

$$
Y=\beta_{0}+\beta_{5} X_{5}+\beta_{6} X_{6}+\beta_{8} X_{8}+\beta_{9} X_{9}+\mu
$$

$Y$ is $\ln$ (growth rate of GDP). $X_{5}$ is $\ln$ (growth rate of commercial banks' domestic currency savings). $X_{6}$ is $\ln$ (growth rate of commercial banks' US dollar savings). $X_{8}$ is $\ln$ (growth rate of exchange rates). $X_{9}$ is $\ln$ (growth rate of credit volume). $\mu$ stands for errors.

The regression results are as follows:

$$
\begin{aligned}
& Y=0.045+0.367 X_{5}+0.199 X_{6}+0.386 X_{8}+0.056 X_{9} \\
& \quad(0.040)(0.118)(0.079)(0.301)(0.031) \\
& t=(1.126)(3.113)(2.502)(1.281) \quad(1.807) \\
& R^{2}=0.624 \quad F=5.808
\end{aligned}
$$

The whole model is all right and acceptable. At the $10 \%$ level of significance test, almost all the variables can pass the ttest. Thus, the conclusions can be drawn as follows:

- When the growth rate of commercial banks' domestic savings rate rises by $1 \%$, the growth rate of GDP rises by $0.367 \%$.

- When the growth rate of commercial banks' US dollar savings rate rises by $1 \%$, the growth rate of GDP rises by $0.199 \%$.

- When the exchange rates increase by $1 \%$, the growth rate of GDP rises by $0.386 \%$.

- When the credit rises by $1 \%$, the growth rate of GDP rises by $0.056 \%$.

Besides, the F-test is significant, and the whole regression equation is passed.

\section{CONCLUSIONS}

By exploring the relationship between Laos' financial reform and economic growth, the analysis shows that there is a long-term relationship between them. The expansion of Laos' financial scale, specifically the growth of the savings and credit of commercial banks have promoted Laos' GDP growth rate.

With Lao commercial banks' savings and credit scale expanding, the loanable funds' market becomes active. In order to promote the further development of the economy, Laos will expand the financial scale, optimize the financial structure, increase commercial banks vitality, and perfect the financial industry laws and regulations to ensure the function of financial markets. In addition, the balance of trade also plays an important role in Laos' economic growth. In other words, Laos increases exports and promotes the economic growth by taking advantage of the fluctuations in exchange rates.

With the promotion of the "One Belt, One Road" policy, China-Laos economies will be linked more closely. From the status quo of Laos' financial reform and its development trend, it's not hard to see that the development and improvement of financial system will help promote economic growth. China and Laos could strengthen the cooperation, especially on their own comparative advantage industry. The more information about Laos, the better the cooperation might be. In the future, the two countries could improve the cooperation in financial industries which has a positive effect on both economic growths.

\section{ACKNOWLEDGMENT}

My paper is supported by the Key Scientific Research Foundation of Education Bureau of Yunnan Province, China (Grant No. 2015Z131).

\section{REFERENCES}

[1] Y. He, "On the 'One Belt, One Road', the Social and Economic Development of Laos”, Journal of Language and Literature Studies, vol.1, 2016, pp. 87-89. (In Chinese)

[2] Rashami and S.H. Wen, "Study on the Relationship between the Financial Reform and Economic Growth in Laos”, Journal of Kunming University of Science and Technology (Social Science Edition), 2013 (13). (In Chinese)

[3] Y.Guo, "Study on the Financial Reform and Development of Laos", Journal of Region Financial Research, vol.5, 2011, pp. 21-27. (In Chinese)

[4] Liu Ding. "Study on Financial Legal Risks in the Implementation of 'One Belt, One Road’ Strategy”. Thesis Monthly .2017,3: 102-118. (In Chinese)

[5] Chen Shuqiong. "Comments on the Development of Foreign Socialist Ideology after the Cold War”. China Foreign Investment .2009,10.203: 242-243. (In Chinese)

[6] Kang Weilai. “Laos’ State-owned Commercial Bank Reform Research”. Master's degree thesis. Jilin University .2007. (In Chinese) 